MILTON AND THE BAROQUE 
By the same author

PROPHET AND POET

BIBLICAL DRAMA IN ENGLAND: FROM THE MIDDLE AGES TO THE PRESENT DAY

THE SOUL OF WIT: A STUDY OF JOHN DONNE 


\section{MILTON AND THE BAROQUE}

Murray Roston

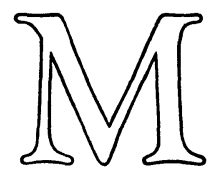


(C) Murray Roston 1980

Softcover reprint of the hardcover 1st edition 1980

All rights reserved. No part of this publication may be reproduced or transmitted, in any form or by any means, without permission

First published 1980 by THE MACMILLAN PRESS LTD

London and Basingstoke Associated companies in Delhi Dublin Hong Kong Johannesburg Lagos Melbourne New York Singapore Tokyo

British Library Cataloguing in Publication Data

Roston, Murray

Milton and the Baroque

I. Milton, John 2. Arts, Baroque

I. Title

$82 \mathrm{I}^{\prime} \cdot 4 \quad \mathrm{PR}_{3588}$

ISBN 978-1-349-04984-4 ISBN 978-1-349-04982-o (eBook) DOI 10.1007/978-1-349-04982-o

This book is sold subject to the standard conditions of the Net Book Agreement 
FOR MY MOTHER 


\section{Contents}

List of Plates viii

Acknowledgements $\quad$ ix

I. The Baroque Vision I

2. The Arch Antagonist 50

3. Corporal Forms 80

4. The War in Heaven $\quad 116$

5. Adventurous Song $\quad 146$

$\begin{array}{ll}\text { Notes } & \text { I } 77\end{array}$

$\begin{array}{ll}\text { Index } & \mathbf{1} 89\end{array}$ 


\section{List of Plates}

I. Andrea Pozzo: The Glory of St. Ignatius, ceiling fresco, S. Ignazio, Rome (Scala, New York)

2. G. B. Gaulli: The Worship of the Holy Name, ceiling fresco, Il Gesù, Rome (Mansell Collection)

3. Vignola: Interior of Il Gesù (Mansell Collection)

4. Bernini: Ceiling of S. Andrea al Quirinale, Rome (Edizioni d' Arte, Rome)

5. Maderno: S. Susanna, Rome (Mansell Collection)

6. Pietro da Cortona: frescoes in the dome and apse of S. Maria in Vallicella, Rome (Mansell Collection)

7. Wren: St. Paul's Cathedral, London (British Travel Association)

8. Rubens: Hercules Slaying Envy, Banqueting Hall, Whitehall, London (Crown copyright-reproduced with permission of the Controller of Her Majesty's Stationery Office)

9. Rubens: The Battle of the Amazons, Alte Pinakothek, Munich (reproduced with permission of Alte Pinakothek, Munich)

10. Hieronymus Bosch: The Fall of the Damned, detail from the left panel of The Haywain triptych, The Prado, Madrid (reproduced with permission of Museo del Prado, Madrid)

I I. Rubens: The Fall of the Damned, Alte Pinakothek, Munich (reproduced with permission of Alte Pinakothek, Munich)

1 2. Pietro da Cortona: stucco decoration in the Sala di Giove, Palazzo Pitti, Florence (Mansell Collection) 


\section{Acknowledgements}

I should like to express my thanks to two colleagues who were kind enough to read this book in manuscript and to make a number of helpful comments: to Professor Harold Fisch for the literary aspects, and Professor M. Barasch for the art history.

The quotations from Paradise Lost are from the edition by Merritt Y. Hughes (New York, 1962) and appear by courtesy of the Odyssey Press.

The Research Committee of Bar-Ilan University assisted me with a grant to cover the cost of typing and the preparation of illustrations, and I am grateful for their help.

Finally, a very special word of thanks to my wife Faith, who accompanied me on my summer tours through the art centres of Europe and, by her own deep love of art and her wide knowledge of its history, made those explorations a shared experience long to be remembered.

M. R. 